\title{
Spotted sand bass, Paralabrax maculatofasciatus, larviculture in Mexico: current status and perspectives
}

\author{
Renato Peña ${ }^{1}$ \\ ${ }^{1}$ Instituto Politécnico Nacional, Centro Interdisciplinario de Ciencias Marinas \\ Unidad Piloto de Maricultivos, La Paz, B.C.S., México \\ Corresponding author: Renato Peña (rpenam@ipn.mx)
}

\begin{abstract}
The spotted sand bass Paralabrax maculatofasciatus is an essential component in the commercial fisheries along the Pacific coast of Mexico. It has been considered as a promising species for seed production under culture conditions, and research have shown that photo-thermal manipulation induces the spotted sand bass broodstock to spontaneously spawn high-quality eggs in captivity almost throughout the year with at least $88 \%$ hatching rate. Additionally, larval performance in intensive culture conditions have shown many favorable characteristics like resistance to high rearing densities (50-100 larvae $\left.\mathrm{L}^{-1}\right)$, acceptance of rotifer Brachionus plicatilis as first prey, fast developmental rate including a totally functional digestive tract around 16 days after hatching (DAH) and high growth rate reaching the juvenile stage in nearly 35-40 DAH with an $11 \%$ survival. In the present review, the main achievements in biological knowledge and culture protocols through larval research of the spotted sand bass during the past 20 years are described, and new research lines and culture parameters towards the establishment of a culture strategy as an economical alternative in the region are proposed.
\end{abstract}

Keywords: Paralabrax maculatofasciatus; spotted sand bass; development; hatching rate; larval culture

\section{INTRODUCTION}

Mexico has over 11,500 km of littoral zone, and despite the vast market for seafood products, marine aquaculture in Mexico at a commercial level is still under developed. Some shrimp species and oysters dominate the commercial production, and extensive aquaculture produces most of the production. Nevertheless, marine fish culture in Mexico has grown in recent years and few species with high economic importance like totoaba Totoaba macdonaldi and spotted rose snapper Lutjanus guttatus have been produced at a commercial scale. However, there have been some efforts by the private and federal sectors to support this activity with other species considered as promising for diversification of commercial marine aquaculture and with relative importance in the national and international markets.

Among these species, the spotted sand bass Paralabrax maculatofasciatus is considered an essential component in local fisheries, reaching a maximum total length (TL) of $60 \mathrm{~cm}$, and its value in the Mexican market has increased in recent years due to its white and tasty meat. It is a serranid distributed from Monterey, California to Mazatlán, Mexico (Miller \& Lea, 1972). At La Paz Bay (in the southern Gulf of California, Mexico: $24^{\circ} 08^{\prime} 32^{\prime \prime} \mathrm{N}, 110^{\circ} 18^{\prime} 39^{\prime \prime} \mathrm{W}$ ), has a reproductive season from January to September when the water temperature is under $28^{\circ} \mathrm{C}$ (Avilés-Quevedo et al., 1995). Broad estimates of fisheries production of sea bass species in the Pacific coast of Mexico report an annual production around 4,500 t.

Research with this species started during the early 90s, when initial trials showed that the spotted sand bass wild broodstock tolerated manipulation after catch and transport to the laboratory, spontaneously spawned in captivity and survived in experimental conditions. Based on these criteria, Matus-Nivón et al. (1990) classified the spotted sand bass as a species with potential for culture. As a result, several academic institutions from northwestern Mexico, including the Centro Interdisciplinario de Ciencias Marinas, the Uni-

Corresponding editor: Eduardo Ballester 
versidad Autónoma de Baja California Sur, the Centro Regional de Investigaciones Pesqueras and the Centro de Investigaciones Biológicas del Noroeste, carried out research programs with the aim of adapting and developing protocols for hatchery production of this species (SEPESCA-UABCS, 1994; Avilés-Quevedo et al., 1995). Those studies confirmed the suitability of this species for culture.

Although culture trials of this species have been carried out during the past 20 years (Civera et al., 2004), cultivation of the spotted sand bass is still at the experimental-pilot level. However, significant improvements have been achieved in broodstock management, gamete production and larval rearing that suggest the possibility to increase seed production to commercial levels. Furthermore, juvenile culture in floating cages has been reported with high growth rates (Avilés-Quevedo et al., 1995; Grayeb-del Álamo, 2001). The present review intends to summarize the current state of biological knowledge achieved through research in the larval culture of the spotted sand bass and to propose new research lines and parameters for consideration in future research towards the development of a culture program as an economical alternative in the region.

\section{Gamete production and egg incubation Gamete production}

The spotted sand bass has been described as a protogynous hermaphrodite (Hastings, 1989; Oda et al., 1993; Lluch-Cota, 1996). Its reproductive season occurs almost throughout the year except September to November, where water temperature fluctuates from 28 to $30^{\circ} \mathrm{C}$. It has an asynchronous ovarian development with a natural tendency to spawn every one or two days (Ocampo-Cervantes, 2002).

Wild broodstock is captured during the reproductive season by hook and line near the southern coast of La Paz Bay, in the southern Gulf of California, and transported to the laboratory where they are immersed in fresh water for $15 \mathrm{~min}$ as a prophylactic measure to dismiss any ectoparasites present in the gills and skin. Then they are placed during two weeks in quarantine tanks, until acclimation, and later sexed by cannulation with a $2 \mathrm{~mm}$ diameter surgical polyethylene cannula.

After the initial acclimation, several culture conditions have been reported to hold the captured broodstock of the spotted sand bass, and successful gonad maturation and spontaneous spawning at these different conditions have been a constant. For instance, Avilés-Quevedo et al. (1995) reported the use of two concrete tanks, of $24 \mathrm{~m}^{3}$ each, with an open flow of untreated seawater, a daily exchange rate of $300 \%$ at a density of 1-1.5 $\mathrm{kg} \mathrm{m}^{-3}$ and a sex proportion of $1: 2$ (male:female). Rosales-Velázquez (1997) reported the use of a culture system, consisting of six 1,100 L fiberglass tanks at $23^{\circ} \mathrm{C}$ and a salinity of 35 , with an artificial photoperiod of $13 \mathrm{~h}$ light: $11 \mathrm{~h}$ dark, water exchange of $20 \mathrm{~L} \mathrm{~min}^{-1}$ and a 1:1 (male:female) sex proportion. Regardless of the conditions used to maintain the broodstock, feeding is at libidum, and the best egg quality has been obtained when they are fed frozen fish (sardines or mojarras) and squid (see egg quality section). Fishes are captured every five days on the adjacent beach of the laboratory and stored in a freezer until fed to the broodstock.

Spawning usually occurs late in the afternoon (18:00-20:00 h), when water temperature fluctuates from 20 to $23^{\circ} \mathrm{C}$, or in the summer during the night $(21: 00-23: 00 \mathrm{~h})$, with water temperature higher than $25^{\circ} \mathrm{C}$ (Avilés-Quevedo et al., 1995). The average daily egg production has been reported to fluctuate from 213,000 eggs d ${ }^{-1}$ from November to April to 59,000 eggs d ${ }^{-1}$ from June to September (Avilés-Quevedo et al., 1995). Martínez-Díaz et al. (2001) described the reproductive behavior of captive broodstock and proposed that a 2:1 (female:male) sex proportion is more suitable to obtain spontaneous spawns every two days. Some efforts to synchronize the reproduction of the spotted sand bass in captivity using a hormonal injection have been reported. Alcántar-Vázquez et al. (2016a) reported the use of the luteinizing hormonereleasing hormone analog to induce final gonad maturation and reproductive performance on wild captured spotted sand bass broodstock. Overall reproductive performance of hormonally-induced spotted sand bass broodstock is significantly lower than the performance observed in spontaneous spawning.

The spotted sand bass spawns round translucent pelagic eggs with an average diameter of $0.84 \pm 0.04$ $\mathrm{mm}$ (mean $\pm \mathrm{SD}$ ) and a single oil globule with an average diameter of $0.16 \pm 0.01 \mathrm{~mm}$ (Butler et al., 1982). Most of the registered fertilization rates are superior to $90 \%$ with a hatching rate superior to $88 \%$ (Avilés-Quevedo et al., 1995; Rosales-Velázquez, 1997; Martínez-Díaz et al., 2001) ensuring a constant egg supply almost all the year. Eggs are collected with a $500 \mu \mathrm{m}$ sieve placed in the drainage of each tank, rinsed with seawater and divided into viable and nonviable by buoyancy in a hypersaline solution (RosalesVelázquez, 1997).

\section{Egg quality}

Egg quality is a central topic in aquaculture for any species. Many factors affect egg quality (Peña, 2015) but broodstock nutrition has received much attention. In the case of the spotted sand bass, some studies 
evaluated the effect of the broodstock diet on egg quality. They compared the effect of frozen food and artificial experimental diets containing different rates of protein (Rosales-Velázquez, 1997), essential fatty acids (Martínez-Brown, 2007) or arachidonic acid (Rodríguez-Trejo, 2008) and using several parameters as a quality criteria including fertilization rate, hatching rate, survival at first feeding and stress resistance. Rosales-Velázquez (1997) reported that the egg production $(716,000-1,200,000)$ and fertilization rate (76-91\%) was significantly higher in the spawns of broodstock fed with frozen fish than the ones fed with an artificial diet containing either 35 or $50 \%$ protein (see Rosales-Velázquez, 1997 for details). Hatch percentage was also higher in the spawns of broodstock fed with frozen fish (89-96\%). No significant difference was observed in the survival to first feeding, with values ranging around $99 \%$. In other experiment, Martínez-Brown (2007) reported that egg quality, in terms of blastomeric morphology, showed significantly better scores in the embryos of broodstock fed frozen mojarra juveniles and squid than in the ones from broodstock fed with artificial experimental diets with two levels of protein (45 and 55\%) and three levels of essential fatty acids (20:4 n-6, 20:5 n-3 and 22:6 n-3) (0.3, 1 and $4 \%$, respectively). Later, Rodríguez-Trejo (2008) reported the effect of artificial diets with different inclusion levels of arachidonic acid (ARA) $(0.17,0.26,0.39$ and $0.68 \%)$ and the use of frozen mojarra (containing $0.26 \%$ of ARA) as control on the reproductive performance of the spotted sand bass and embryo and larval quality. Fecundity was significantly higher when $0.17 \%$ of ARA was included in the diet (average of 66,074 eggs per spawn); however, egg viability was significantly higher when frozen mojarra was offered as food $(78.8 \%)$. ARA percentage in the diet did not affect hatching rate (interval 95 to $99 \%$ ). Blastomeric morphology had a significantly higher value with $0.17 \%$ of ARA and mojarra feeds.

These results showed that the best option remains to be fresh or frozen food (mojarra, squid or sardine). However, it is evident that more studies are necessary to gain more knowledge about the nutritional requirements of the broodstock and the effects of different feeds on egg quality. It is necessary to evaluate the effect of the inclusion of other nutrients like vitamins $\mathrm{E}$ and $\mathrm{C}$, carotenoids and phospholipids, as well as alternative protein sources and to define the criteria to evaluate egg quality (Peña, 2015).

\section{Egg incubation}

After a rinse in seawater, fertilized eggs are incubated in two $120 \mathrm{~L}$ cylinder-conical tanks. The average incubation density fluctuates from 700 to $900 \mathrm{eggs} \mathrm{L}^{-1}$.
Incubation temperature fluctuates around $23-26^{\circ} \mathrm{C}$, while salinity varies from 32-35 (Ortiz-Galindo et al., 2000a; Futema-Jiménez, 2004). Incubation conditions include slight aeration from the bottom to promote a homogeneous distribution of the eggs in the water column; continuous flow (500 mL min $\left.{ }^{-1}\right)$; the light intensity at water surface around 400 lux; and an artificial photoperiod of 12:12 light:dark. Dead eggs are siphoned every $12 \mathrm{~h}$ to avoid contamination and proliferation of ciliates.

Under these conditions, the hatching rate is above $90 \%$ throughout the year. Some studies showed that hatching rate is not significantly affected by salinity or temperature under an interval of 20 to 50 or 20 to $29^{\circ} \mathrm{C}$, respectively (Ortiz-Galindo et al., 2000a; FutemaJiménez, 2004). However, time to hatch is thermodependent, reducing from 35 to $17 \mathrm{~h}$ at 20 and $29^{\circ} \mathrm{C}$, respectively, regardless of salinity (30-40) (FutemaJiménez, 2004). To reduce death by mechanical collapse eggs are not manipulated before the closure of the blastopore (approx. 8-10 h after fertilization) (Martínez-Díaz et al., 2001).

\section{Biology of spotted sand bass larvae}

The growth of the spotted sand bass larvae during the first 30 days of development follows an exponential curve (Peña et al., 2003). As in most marine fish species, the early development of the spotted sand bass is characterized by the presence of a larval period divided into four stages (yolk-sac larva, preflexion larva, flexion larva and postflexion larva) and a juvenile period. Each stage is characterized by specific growth patterns with different morphological characteristics and functional capacities with significant implications in the development of rearing protocols.

Right after hatching, the yolk-sac larva stage shows an incipient developmental state, lacking most organs and systems. Average total length is $1.50 \pm 0.10 \mathrm{~mm}$, and a single oil globule (diameter of $0.13 \pm 0.06 \mathrm{~mm}$ ) is present in the anterior portion of the yolk sac (Butler et al., 1982). Nevertheless, at $25^{\circ} \mathrm{C}$, the duration of the yolk-sac larva stage is about 2-2.5 days. During this time, nutrition relies on the yolk and oil globule, mouth and anus are closed. However, mouthparts like the Meckel's, quadrate, hyoid and hyomandibular cartilages were evident (Ortiz-Galindo et al., 2000b). The digestive tract is located in the dorsal region of the yolk sac and can be divided into three segments: foregut, midgut and hindgut without an evident cellular differentiation. Pancreas and liver are not observed at hatching (Peña et al., 2003). However, digestive enzymatic activity has been detected from hatching and was suggested as a mechanism of yolk digestion since no food consumption occurs during the first two days 
of development (Álvarez-González et al., 2001a). The visual system is undifferentiated. The eye is composed by the lens and a retina formed by undifferentiated cells in a centrifugal arrangement without pigmentation and surrounded by a sclera of connective tissue, and the optic nerve is observed at this stage (Peña \& Dumas, 2007).

During the next $48 \mathrm{~h}$, along with the consumption of the nutritional reserves, morphological and physiological changes directed to start feeding and predator avoidance are observed. The morphological growth and development of body segments (like head and tail) during the endogenous nutrition period, have shown a higher growth coefficient when compared to the growth coefficient of the trunk. Therefore, suggesting that head and tail segments develop at a higher rate, in order to emphasize basic functions like feeding, swimming and predator avoidance by prioritizing the differentiation of the nervous system, the sensory organs and feeding apparatus in the head and the muscular tissue in the tail segment (Peña \& Dumas, 2009). The endogenous feeding period lasted two days at $25^{\circ} \mathrm{C}$, while the complete depletion of the oil globule may take one more day at this temperature (Peña et al., 2003). It is common to observe a short (less than $24 \mathrm{~h}$ long) mix-feeding period during which the mouth and anus open to allow prey ingestion, signaling the onset of exogenous feeding while the oil globule is still present.

The yolk sac and oil globule are completely depleted at $3 \mathrm{DAH}$ (Days after hatching), signaling the start of the pre-flexion larvae stage. From this moment, the food source is entirely exogenous which implies that larvae must start searching for prey and develop a feeding behavior. Some observations at the time of first feeding have shown that an increase in larval activity is evident within the first minute after prey addition in the rearing tanks. Several modal action patterns were identified, including an "S" posture before each attack (Peña, unpubl. data). At the time of first feeding, initial mouth size is $223.3 \pm 35.1 \mu \mathrm{m}$ and increases linearly (y $=-11.20+144.01 \mathrm{x} ; \mathrm{r}=0.93)$ with development reaching $1062.5 \pm 149.3 \mu \mathrm{m}$ at $18 \mathrm{DAH}$. Also at the time of first feeding, in the eye, the pigment epithelium layer is evident surrounding the nuclear layer of the retina, and single cones are the only photoreceptors observed at this time, which increase in number during the pre-flexion stage (Peña \& Dumas, 2007). The morphological development of the spotted sand bass larvae during the pre-flexion stage show positive allometric growth of the head segment, while in the trunk and tail segments growth is negatively allometric. However, specific body proportions like head depth, body depth, musculature height, mouth length and eye diameter show positive allometry suggesting a tendency to an increment of the feeding and swimming capacities and the ingestion of larger prey (Peña \& Dumas, 2009).

Studies related to digestive physiology have shown that from the time of first feeding, the spotted sand bass larvae have a full set of enzymatic activity, which allows them to digest the ingested food successfully. Alkaline proteases, trypsin, chymotrypsin, esterase, amylase and phosphatases have been detected using photometric techniques (Álvarez-González, 2003). Peña et al. (2009), using enzyme histochemistry, showed the importance of the intestinal mucosa as a site of action of digestive enzymatic activity of aminopeptidase M, dipeptidyl aminopeptidase IV, nonspecific esterase and alkaline and acid phosphatases from first feeding and throughout the larval development.

The flexion stage of $P$. maculatofasciatus starts at $12 \mathrm{DAH}$. It is characterized by the presence of a $45^{\circ}$ upward turn of the notochord tip. Some fin elements like caudal rays and pelvic buds start to develop. During the stage, the fin fold narrowed in the caudal peduncle. The morphological development during this stage showed a change in the growth coefficients of the head, trunk and tail segments.

Furthermore, the appearance of an inflection point of the growth coefficient, from most body proportions, suggests that significant morphological and physiological changes occur during this stage (Peña \& Dumas, 2009). Indeed, a major event with important implications for nutrient digestion and feeding protocols occur during the flexion stage. The appearance of differentiated gastric glands in the antero-medium region of the stomach, along with the first pyloric caeca was first recorded at $16 \mathrm{DAH}$ in larvae with an average $\mathrm{TL}$ of $7.3 \pm 1.4 \mathrm{~mm}$ (Peña et al., 2003). The appearance of gastric glands is an important biomarker of the development of the digestive function in fish larvae since it leads to the secretion of $\mathrm{HCl}$ and pepsin, the primary enzyme involved in protein digestion, which was also reported during the flexion stage in the spotted sand bass larvae (Álvarez-González, 2003). Other significant biological changes occur in the visual system during the flexion stage, for instance, the appearance of the first double cones in the retina is observed at $14 \mathrm{DAH}$, and some rod precursor cells are observed two days later. These changes in the photoreceptors of the retina will increase neural synapses and improve visual function.

Morphologically and osteologically, the end of the flexion stage is observed with the appearance of the pelvic, anal and dorsal fins with pigmented rays (OrtizGalindo et al., 2000b). The postflexion stage initiates 
from $18 \mathrm{DAH}$, and during this period, a certain tendency to isometry in tail, head and trunk segments is observed while in other body proportions positive allometry (tail depth and musculature height) and negative allometry (head depth) is still observed (Peña $\&$ Dumas, 2009). This change to isometry during the postflexion stage in fish larvae has been considered as a natural transition in growth priorities since primary functions have been fulfilled during the early developmental stages. No major changes occur in the digestive tract during this stage, except for the appearance of new pyloric caeca and the increase of the enzymatic activity. However, a new type of photoreceptor appeared in the eye. The rods are observed in the retina, and from his point a duplex retina with both rods and cones is present, improving visual capacity, with a concomitant increase in prey detection and ingestion in a broader range of light intensities, which is essential in the wild. After a pelagic larval stage, the spotted sand bass changes to a benthic lifestyle during its transformation into a juvenile. In culture conditions, this change in the spatial distribution has been observed around days 29-30, when the first juveniles are observed. From this day onwards the juvenile stage is characterized by the completion of squamation of the body surface, the appearance of the typical coloration of the species and accelerate body growth.

\section{Larval rearing conditions}

Larviculture of the spotted sand bass started during the early 90s. First trials were performed in $40 \mathrm{~L}$ glass aquaria without rigorous control of culture conditions or feeding protocols. However, it was possible to evaluate the effect of rearing temperature on survival and larval viability during the first days of development, and the best rearing conditions during the endogenous feeding period were 23 to $26^{\circ} \mathrm{C}$ and 30 to 35 salinity (Futema-Jiménez, 2004).

These parameters were considered during the introduction of a closed recirculating seawater system for experimental larviculture at the end of the 90s. The system consisted of sixteen semi-square fiberglass tanks (each tank with a total volume of $120 \mathrm{~L}$ ) with round corners and grey walls. Incoming water was mechanically filtered to remove suspended solids (pressurized sand filter) and a $5 \mu \mathrm{m}$ cartridge filter; and passed across a biological filter, before being UVsterilized and pumped to the rearing tanks (ÁlvarezGonzález, 1999). Rearing conditions in this system during several 30-days culture trials fluctuated around a temperature of $24-26^{\circ} \mathrm{C}$, salinity $34-35$, ammonium near 0-0.8 ppm and photoperiod 13:11 (light:dark) provided by full-spectrum fluorescent white lamps and a light intensity of 400-500 lux at the water surface. The next step was to establish the effect of larval stocking density, since it is an important factor when intensive culture systems are used because it affects water quality, food production, growth and survival. Four stocking densities were tested (50, 100, 150 and 200 larvae $\mathrm{L}^{-1}$ ) over a 30 days experiment and the results showed that larvae raised at the lower densities were significantly larger with a higher survival and more resistant to a stress test, therefore, 50 larvae $\mathrm{L}^{-1}$ was recommended as an optimal density for larval culture of the spotted sand bass (Álvarez-González et al., 2001b).

Since then, a large part of the research in our laboratory was oriented to evaluate the effect of other culture conditions on larval performance and feeding. Since culture conditions that enhance feeding efficiency at first feeding may contribute to increase survival rates and reduce the risk of starvation during the first days of development, and also provide vital information to modify and improve the rearing protocols. In a first study, the effect of light intensity on feeding success at first feeding was evaluated (Peña $e t$ al., 2004). The study confirmed that spotted sand bass larvae are visual predators and the highest light intensity tested (700 lux) induced a better feeding performance by the larvae. In another experiment, it was evaluated the effect of tank color (white, grey and black) and prey density $\left(5,10\right.$ and 15 prey $\left.\mathrm{mL}^{-1}\right)$ on feeding performance at first feeding; while tank color had no effect on feeding incidence, feeding intensity was significantly augmented at the highest prey density (Peña et al., 2005). Considering these results, the tank color was changed from entirely grey to black walls and white bottom, and the use of cylinder-conical tanks with a total volume of $180 \mathrm{~L}$ was started. An increment of prey density from 3 to 15 prey $\mathrm{mL}^{-1}$ and $700-800$ lux of light intensity at water surface was introduced in the rearing system. Along with the search of the optimum culture conditions, part of the research was focused in the development of an optimal feeding schedule that may increase survival during larval culture, which is described in the next section.

\section{Larval feeding}

During culture conditions, an optimal feeding protocol is essential to ensure growth and survival. In this regard, and as in other marine fish species, two stages have been considered as critical: first feeding and weaning. Larvae are most vulnerable to starvation, and any delay in first feeding may affect growth and induce death by starvation. Peña \& Dumas (2005) evaluated the effect of early starvation on the feeding ability and development by delaying first feeding, and concluded 


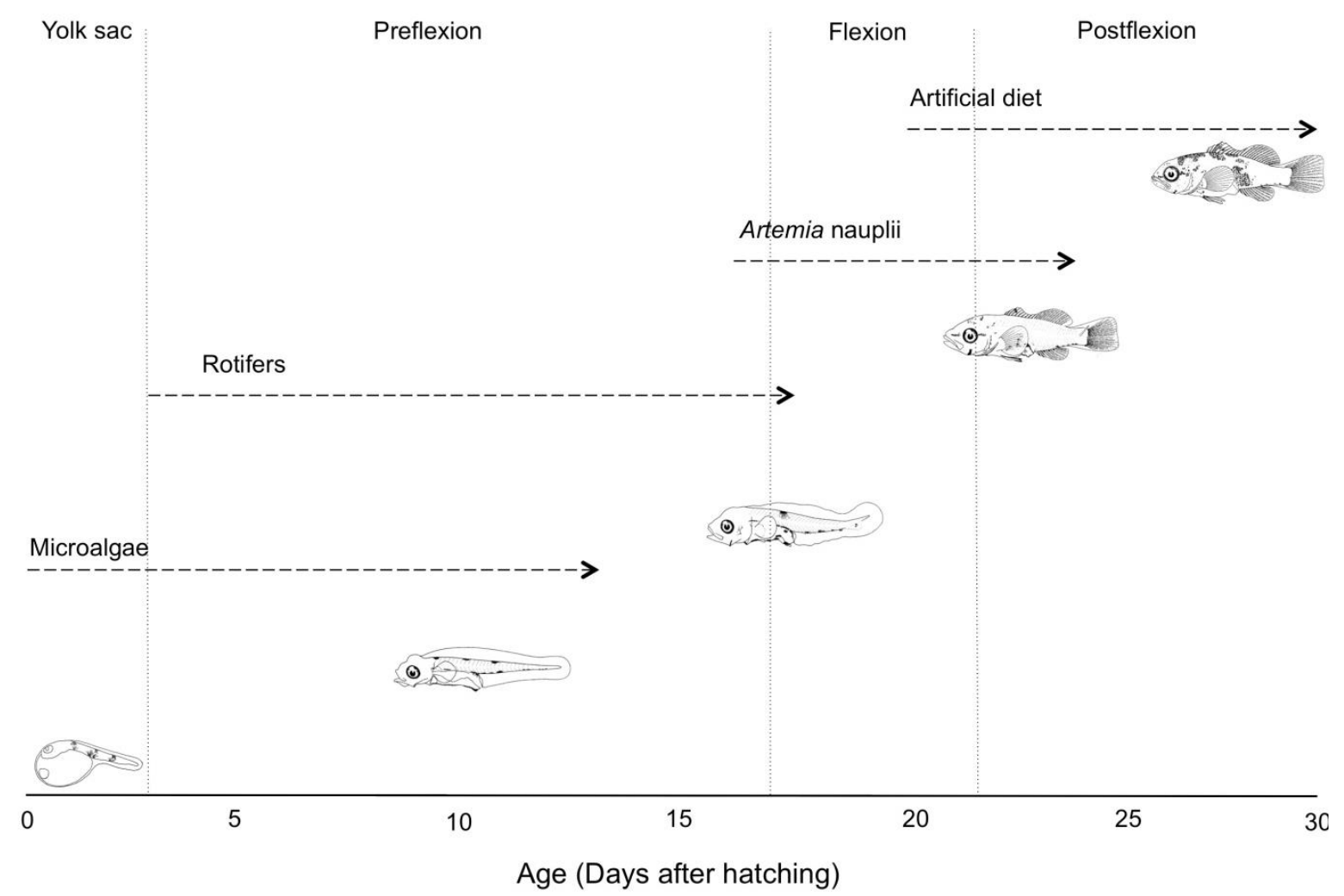

Figure 1. Feeding schedule during the spotted sand bass larval culture in Mexico with a short co-feeding period, during the transition of flexion and postflexion larvae.

that the spotted sand bass larvae might tolerate two or three days without feeding during the first days of development in culture conditions. Regarding weaning, some studies have reported the adverse effect of early weaning on growth, survival or nutritional condition of the larvae. Nevertheless, a primary feeding schedule has been established based mostly on live prey (rotifers and Artemia nauplii) and early weaning during the third or fourth week of development, which is shown in Figure 1.

\section{Live feeds}

Larviculture of the spotted sand bass follows the intensive method, which is characterized by a high larval stocking density and the constant addition of live feed throughout the culture period (Shields, 2001). As part of the same method, microalgae have been added to the rearing tanks during the first weeks, which is known as the technique of "green water". The main species used are Nannochloris sp. and Nannochloropsis oculata at a density that fluctuates from 200,000 to 600,000 cell mL ${ }^{-1}$ (Martínez-Díaz et al., 2001; GarcíaGómez, 2003; Futema-Jiménez, 2004; Peña, 2005).

Since the early trials, feeding during the first weeks of the larval culture of the spotted sand bass consisted of live prey. The different prey types offered in several studies included the rotifers Brachionus plicatilis and $B$. rotundiformis; the brine shrimp Artemia at several life stages (i.e., nauplii, juveniles and adults); copepods Pseudodiaptomus euryhalinus at several life stages (nauplii, copepodites and adults); wild zooplankton; and even yolk sac larvae from the same species. However, there has been no consistency in prey density or the time they have been offered. In some cases, the prey was offered as low as 1 prey $\mathrm{mL}^{-1}$ during 10 days while others offered 10 prey $\mathrm{mL}^{-1}$ for five days, and in some cases, prey density was subject to prey production. Table 1 shows some of the prey densities and time offered during the larval culture of the spotted sand bass.

In an attempt to establish the live food requirements and to optimize rotifers and Artemia production during the larval culture of the spotted sand bass larvae, the feeding efficiency in terms of the feeding incidence (percentage of larvae with prey) and the feeding intensity (number of prey in the digestive tract) was evaluated during larval rearing. Starting at the time of first feeding at $2 \mathrm{DAH}$ and until $25 \mathrm{DAH}, 30$ larvae were collected one hour after feeding. Larvae were anesthetized and the digestive tract dissected for direct 
Table 1. Main prey type, density and number of days offered during different trials of the larval culture of the spotted sand bass Paralabrax maculatofasciatus. DAH: Days after hatching.

\begin{tabular}{lccl}
\hline Prey & Density $\left(\right.$ prey $\left.\mathrm{mL}^{-1}\right)$ & Period offered (DAH) & Reference \\
\hline & $5-10$ & $2-17$ & Martínez-Díaz (2001) \\
& $5-35$ & $3-24$ & Anguas-Velez et al. (2000) \\
& $2.4-10$ & $2-23$ & Futema-Jiménez (2004) \\
Brachionus plicatilis & $1-20$ & $1-15$ & García-Gómez (2003) \\
& 5 & $2-15$ & Pliego-Cortés (2005) \\
& $2-4$ & $2-16$ & García-Gómez (2006) \\
& 5 & $2-13$ & Peña and Dumas (2009) \\
& 5 & $2-21$ & Roldan-Libenson et al. (1999) \\
\cline { 2 - 4 } Artemia nauplii & 1 & $15-17$ & Martínez-Díaz (2001) \\
& $0.1-3$ & $12-31$ & Futema-Jiménez (2004) \\
& $1.5-10$ & $15-25$ & García-Gómez (2003) \\
& $3-5$ & $13-23$ & Peña and Dumas (2005) \\
& 3 & $15-21$ & Pliego-Cortés (2005) \\
& $2-6$ & $15-23$ & García-Gómez (2006) \\
Artemia juvenile & 5 & $12-19$ & Peña and Dumas (2009) \\
& $5-50$ & $27-39$ & Anguas-Velez et al. (2000) \\
& 3 & $21-33$ & Pliego-Cortés (2005) \\
& $0.2-0.5$ & $22-25$ & García-Gómez (2006) \\
& 0.1 & $18-30$ & Peña and Dumas (2009) \\
\hline
\end{tabular}

counting of the prey number of the digestive tract (Peña, 2005). Feeding incidence at first feeding was $35 \%$ and significantly augmented to $96 \%$ on the next day. From 7 DAH feeding incidence was $100 \%$. The initial feeding intensity was 1 rotifer/larvae and increased with development. Three stages of feeding intensity were identified (Fig. 2). The first stage, from 2 to $6 \mathrm{DAH}$, when feeding intensity remained below 15 rotifers/larvae. A second stage occurred from days 712 , when a significantly higher feeding intensity was recorded, reaching a peak at $10 \mathrm{DAH}$ with $56.9 \pm 9.6$ rotifers/larvae. Feeding intensity during the first 12 days of development was significantly related to the height of the digestive tract $\left(\mathrm{R}^{2}=0.960 ; \mathrm{y}=\right.$ $\left.3236.21 \mathrm{x}^{2.96}\right)$. The third stage occurs after the addition on Artemia nauplii and a drastic drop in the rotifer ingestion was observed while an evident larval selection for Artemia nauplii increased from $2.8 \pm 1.9$ at $12 \mathrm{DAH}$ to $28.1 \pm 3.7$ at $25 \mathrm{DAH}$ (Peña, 2005).

To cover the nutritional requirements for optimal growth and development of the larvae, and due to the well-documented deficiencies in essential fatty acids of rotifers and Artemia (Sargent et al., 1997), an enrichment process is a common practice in the larviculture. Enrichment techniques have been based on the use of commercial emulsions following the manufacturer instructions. However, in an early attempt to find alternative oil sources for rotifers enrichment, Roldán-Libenson et al. (1999) tested the effect of red crab Pleuroncodes planipes and squid oils as enrichment for the rotifer Brachionus plicatilis on the growth and survival of the spotted sand bass larvae. Rotifers were offered during 21 days, and at the end of the experiment, no significant differences were reported neither in larval growth nor survival between enrichment treatments.

\section{Co-feeding and weaning}

Substituting live prey with an inert diet is a central topic in larviculture since the early addition of an artificial diet will reduce the costs involved in larval feeding, which have been reported to be around the $40 \%$ of the total production costs. Many reports, with different species, have shown that a direct and sudden change from live prey to artificial diet, particularly at first feeding or few days after have a negative impact on larval survival. Therefore, in most species, a co-feeding period in which both, live prey and inert diet are offered during several days, with a progressive increase of the artificial diet and a decrease of the amount of live prey, until the last day, when the larvae are fed entirely on the inert diet from that day onwards, and the larvae have been weaned. Particularly important for the success of this process are the larval age at the onset of co-feeding and the number of days that larvae are co-fed.

Regarding the spotted sand bass larvae, several trials have been reported on early weaning. Interestingly, 


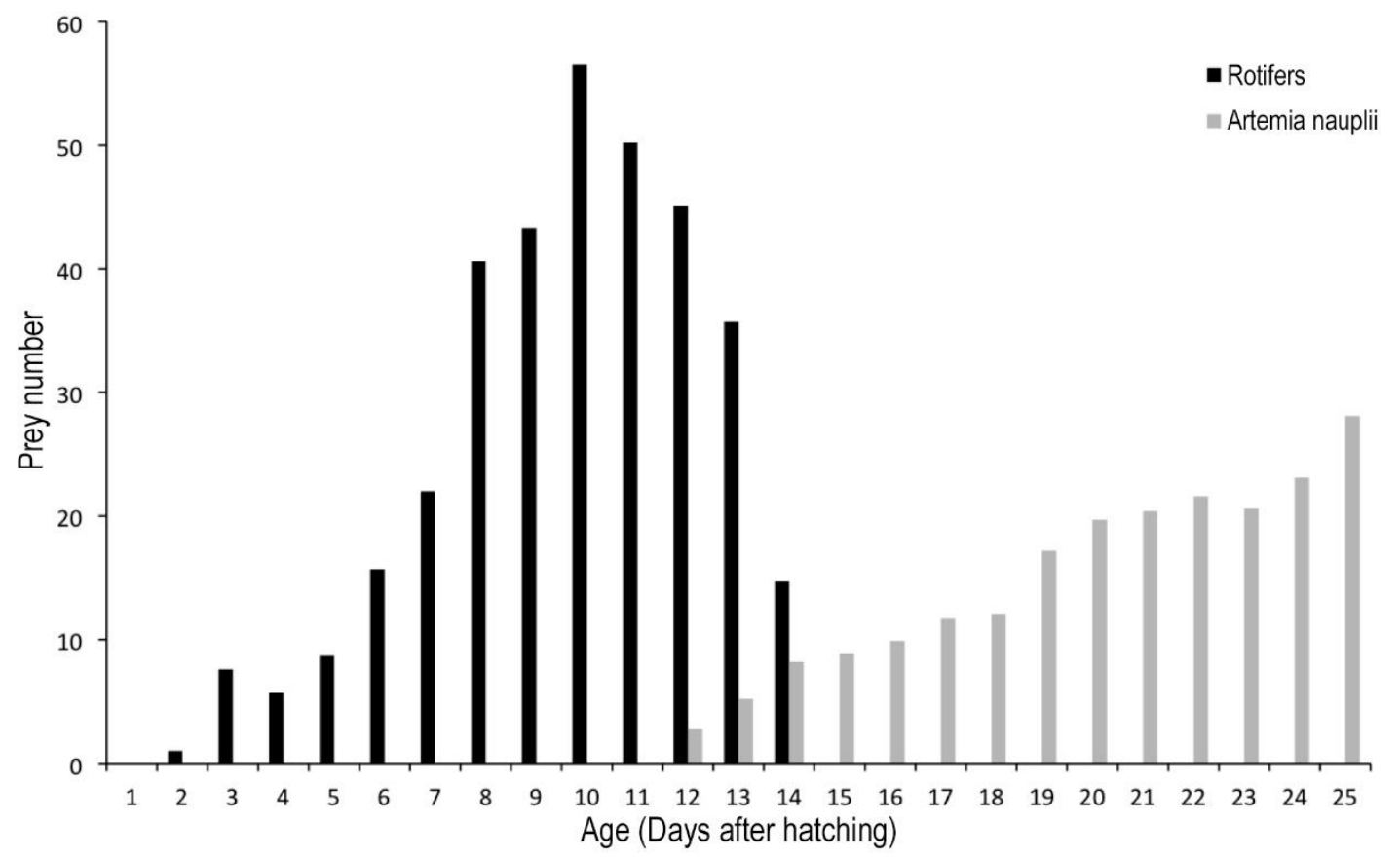

Figure 2. Feeding intensity during larval culture of the spotted sand bass Paralabrax maculatofasciatus.

most of the research in this regard has been conducted to evaluate the larval performance using different experimental diets (with different protein content and protein sources) rather than a commercial one. Cofeeding has been implemented as a weaning strategy. However, an average of four-five days of the cofeeding period has been a constant in these experiments, and overall, poor larval performance in terms of growth or survival compared with the larvae fed live prey has been reported after weaning.

The first report was by Anguas-Vélez et al. (2000). Larvae were weaned at 15, 25 and 30 DAH using a four days co-feeding period. Fishmeal was the primary protein ingredient, and the protein percentage was 55.38. The larvae weaned at $15 \mathrm{DAH}$ did not survive after $20 \mathrm{DAH}$. On the other hand, the larvae weaned at 25 and 30 DAH along with the control larvae (fed with live prey) survived until $45 \mathrm{DAH}$, but no significant differences were detected in growth, survival rates or condition factor. The authors recommended that early weaning should not be before $30 \mathrm{DAH}$. However, after this study, relevant information regarding the digestive capabilities of the spotted sand bass larvae was reported, which led to new study design to evaluate the time for early weaning after the day of appearance of gastric glands in the stomach and pepsin activity. In this new study, three microparticulate diets with different protein source (squid meal, beef blood meal and a commercial protein hydrolysate with a crude protein content of 52.2, 55.1, and 57.5\%, respectively) and two weaning times (17 and $22 \mathrm{DAH}$ ) were evaluated with a co-feeding period of only three days. Overall, weaning of spotted sand bass at $17 \mathrm{DAH}$ resulted in poor larval performance. However, in the other treatment, when the larvae were weaned at $22 \mathrm{DAH}$, larger larvae and a higher survival rate were observed with the protein hydrolysate and the squid meal diets (ÁlvarezGonzález, 2003; Civera-Cerecedo et al., 2008).

Considering the possible adverse effects of early weaning on larval performance, Pliego-Cortés (2005) tested the effect of early weaning on the nutritional condition of the larvae. He reported the use of an experimental micro-particulate diet which included decapsulated cysts of Artemia and fish meal as a protein source (48\% protein). Larvae were weaned from 17 DAH using a four days co-feeding period. Significant morphological and physiological effects on the larvae due to the micro-diet were evident from $21 \mathrm{DAH}$, being the enterocytes height and the ARN/ADN ratio efficient variables in detecting the early effects of weaning on the nutritional condition of the larvae.

In another attempt to successfully wean this species, García-Gómez (2006) tested a micro-capsulated artificial diet. Two types of microcapsules were used, one with squid meal as a protein source and the other with fish hydrolysate and squid meal. The protein content of the diets was 59.05 and 61.50 , respectively. The experiment started from $15 \mathrm{DAH}$ and five days of the co-feeding period was applied. At the end of the 
experiment (day 25) larval length was similar between control larvae and larvae fed with the microcapsules with fish hydrolysate and squid meal; while larval survival was significantly higher in the larvae fed live prey. Nevertheless, the use of microcapsules seems a promising alternative although more studies are necessary to adequately establish and analyze the effect on nutritional condition and growth rate.

\section{Growth and survival}

As in other species, high mortality has been recorded during the transition from an endogenous to an exogenous feeding in the spotted sand bass larvae. Survival from hatching to first feeding varies significantly due to temperature and salinity, highest survival $(77 \%)$ occurred at $23^{\circ} \mathrm{C}$ and salinity 30 . Nevertheless, notochordal length at first feeding is significantly higher at $26^{\circ}$ and salinity $35(2.66 \mathrm{~mm})$ than at $23^{\circ}$ and salinity $30(2.58 \mathrm{~mm})$ (Futema-Jiménez, 2004).

Spotted sand bass larvae usually reach the juvenile period at approximately 30-35 days after hatching, and most of the studies previously mentioned tend to evaluate survival at day 30 since no significant mortality has been reported after this day. At an experimental level, the reported survival rates of the spotted sand bass larvae varied widely. The lowest survival rate was reported by Futema-Jiménez (2004) with only $0.8 \%$ at day 30 , while the highest larval survival rate was reported by Álvarez-González et al. (2001b) with $11 \%$ at 30 DAH (Table 2). Particular culture conditions that allowed this survival included a larval density of 50 larvae $\mathrm{L}^{-1}, 25^{\circ} \mathrm{C}$, salinity $34,3.67$ $\mathrm{mg} \mathrm{L}^{-1} \mathrm{O}_{2}$, a 13:11 (light:dark) photoperiod, a progressive increment of water flow and feeding during that study consisted on live prey, no artificial diet was offered to the larvae. Since then, these culture conditions have been used during the larval culture of the spotted sand bass.

Nevertheless, it is essential to consider that in most of those reports the evaluated larval survival does not consider sampled larvae, which sometimes can be very high due to the quantity of sample required for a specific analysis, like enzymatic activity during development. So there is still the need to evaluate larval survival under optimal conditions without larval sampling except for the evaluation of length and weight growth. Additionally, older larvae (postflexion) are highly cannibalistic, and the effect on survival has yet to be determined.

\section{Growth of juveniles in floating cages}

Following the larval culture under intensive conditions, the juvenile culture in floating cages is the next step that
Table 2. Larval survival of the spotted sand bass Paralabrax maculatofasciatus, at different days during larval culture.

\begin{tabular}{cll}
\hline Survival at day & Survival (\%) & \multicolumn{1}{c}{ Reference } \\
\hline 17 & 5.3 & Martínez Díaz et al. $(2001)$ \\
20 & 5.2 & Anguas-Vélez et al. $(2000)$ \\
21 & $5.7-6.4$ & Roldán-Libenson et al. $(1999)$ \\
25 & 6.42 & García-Gómez (2006) \\
30 & 0.8 & Futema-Jimenez (2004) \\
30 & 2.5 & Avilés-Quevedo et al. $(1995)$ \\
30 & $3.5-7.6$ & Contreras-Olguín et al. $(1997)$ \\
30 & $5.0-11$ & Álvarez-González et al. $(2001)$ \\
40 & $2.3-4.6$ & Civera-Cerecedo et al. $(2008)$ \\
45 & $1.7-2.7$ & Anguas-Vélez et al. $(2000)$ \\
\hline
\end{tabular}

has been reported in the culture process of the spotted sand bass. Two studies on this regard have been reported, and overall, the high growth rate of the juvenile is evident. Avilés-Quevedo et al. (1995) reported that the spotted sand bass juveniles, reared in floating cages, reached a commercial size of $25 \mathrm{~cm}$ in 10 months when starting with juveniles of an initial TL of $6.7 \mathrm{~cm}$ and at an initial density of 400 fish $\mathrm{m}^{-3}$. In another study, Grayeb-del Álamo (2001) reported that the best growth rate of $1.3 \mathrm{~g}$ juveniles in floating cages during 84 days were obtained at an initial density of 70 fish $\mathrm{m}^{-3}$, with an average survival of $90 \%$ and a final weight of $25.6 \mathrm{~g}$. Juveniles were fed with a diet containing $55 \%$ protein and $22 \%$ lipids. Additionally, in another experiment, juveniles of $22 \mathrm{~g}$ cultivated during 151 days in floating cages at an initial density of $300 \mathrm{~g} \mathrm{~m}^{-3}$, fed with the same diet as in the previous experiment, reached $55 \mathrm{~g}$ with a $90 \%$ survival.

\section{Perspectives}

The larval culture of the spotted sand bass has reached a level where the fundamental aspects of its culture have been covered. However, to increase seed production by optimizing the current rearing protocols and accelerating the commercial viability of this species, many areas need further research.

Studies to improve feeding strategies must be a priority. A first alternative should be to increase the duration of the co-feeding period. Some studies in other species have shown that co-feeding length increments larval survival, even when it is initiated at an early age (Shields, 2001). An important aspect will be the continuous evaluation of new artificial diets either commercial or experimental with different protein sources. In this regard, the inclusion and evaluation of nutritional and immune additives in the diet like free amino acids, probiotics or prebiotics have proved to be an important topic; and the development of an integrated strategy to evaluate the nutritional condition 
of the larvae after weaning should be considered. Also, the presence of developmental abnormalities has not been a problem during the larval rearing of spotted sand bass, the occurrence of morpho-anatomical deformities is less than one percent in every trial reported (Peña, unpubl. data) but should be regularly monitored.

At present, research is being carried out regarding the development of the immune function, including the differentiation of lymphoid organs to evaluate the use of vaccines and immuno-stimulants during early development and weaning. Despite recent advances in evaluating the digestive capability of the spotted sand bass larvae, there is still the lack of defining their nutritional requirements and digestibility of different ingredients. Broodstock nutrition and egg quality evaluation should be included in future research. The optimization of larviculture production should consider technical advances in culture equipment and also the evaluation of the effect of several biotic and abiotic factors like light intensity, turbidity and prey densities.

Finally, as in other species of this family, protogynous hermaphroditism is present (Hastings, 1989; Oda et al., 1993; Lluch-Cota, 1996; OcampoCervantes, 2002), leading to early gonad maturation, reducing juvenile growth rates. The induction and production of triploid larvae-juveniles have been evaluated as an alternative to counteract the early gonad maturation of the spotted sand bass. In this regard, the method to induce triploidy by cold shock and the optimal experimental conditions to produce high percentage (90-100\%) of triploid larvae at hatching has been reported (Alcántar-Vázquez et al., 2008). However, a low survival rate of triploid larvae at day $30 \quad(<2 \%)$ were reported in another experiment (Alcántar-Vázquez et al., 2016b), therefore, optimization of triploid production and cultivation should be considered in further research.

\section{CONCLUSIONS}

This review shows that there has been acceptable progress in the larval culture of the spotted sand bass, during approximately 20 years of research. Despite the different areas that need further research, the actual state of the larval culture of the spotted sand bass may allow us to go further in trying to increase seed production to promote investment from government and the private sector. In the meantime, the spotted sand bass has proved to be a valuable biological model for experimentation and analysis of the development and differentiation of marine fish larvae. It allows us to gain the necessary knowledge to better understand different areas like digestive physiology, feeding efficiency, nutritional condition, evaluation of the larval quality and the effects of abiotic conditions during early development. This knowledge has been advantageous to improve the rearing protocols of other important marine species in the Pacific coast of Mexico.

\section{REFERENCES}

Alcántar-Vázquez, J.P., Dumas, S., Peña, R. \& Ibarra, A.I. 2016b. Effects of cold-shock triploidy induction treatment on cell cleavage hatching rate, and survival of triploid larvae of spotted sand bass (Paralabrax maculatofasciatus). Ciencias Marinas, 42(2): 111-122.

Alcántar-Vázquez, J.P., Dumas, S., Puente-Carreón, E., Pliego-Cortés, H.S. \& Peña, R. 2008. Induction of triploidy in spotted sand bass (Paralabrax maculatofasciatus Steindachner, 1868) by cold shock. Aquaculture Research, 39: 59-63.

Alcántar-Vázquez, J.P., Pliego-Cortés, H.S., Dumas, S., Peña, R., Rosales-Velázquez, M. \& Pintos-Terán, P. 2016a. Effects of a luteinizing hormone-releasing hormone analogue (LHRHa) on the reproductive performance of spotted sand bass Paralabrax maculatofasciatus (Percoidei: Serranidae). Latin American Journal of Aquatic Research, 44(3): 487-496.

Álvarez-González, C.A. 2003. Actividad enzimática digestiva y evaluación de dietas para el destete de larvas de cabrilla arenera Paralabrax maculatofasciatus (Percoidei: Serranidae). Doctorate Thesis, Centro Interdisciplinario de Ciencias Marinas, Instituto Politécnico Nacional, Ciudad de México, 164 pp.

Álvarez-González, C.A. 1999. Optimización del proceso de producción de semilla de la cabrilla arenera Paralabrax maculatofasciatus (Percoidei: Serranidae) en sistemas de circulación cerrada. Master's Thesis, Centro Interdisciplinario de Ciencias Marinas, Instituto Politécnico Nacional, Ciudad de México, 108 pp.

Álvarez-González, C.A., Nolasco-Soria, H., CiveraCerecedo, R., Dumas, S., Ortiz-Galindo, J.L. \& Rosales-Velázquez, M. 2001a. Development of some digestive enzymes in spotted sand bass Paralabrax maculatofasciatus larvae. In: Hendry, C.I., Van Stappen, G., Wille, M. \& Sorgeloos, P. (Eds.) Larvi 2001: $3^{\text {rd }}$ Fish \& Shellfish Larviculture Symposium. Gent, Belgium, 3-6 September, European Aquaculture Society, Oostende, $4 \mathrm{pp}$.

Álvarez-González, C.A., Ortiz-Galindo, J.L., Dumas, S., Martínez-Díaz, S., Hernández, D.E., Grayeb-del Álamo, T., Moreno-Legorreta, M., Peña, R. \& CiveraCerecedo, R. 2001b. Effect of stocking density on the growth and survival of spotted sand bass Paralabrax maculatofasciatus larvae in a closed recirculating system. Journal of the World Aquaculture Society, 32: 130-137. 
Anguas-Vélez, B.H., Civera-Cerecedo, R., ContrerasOlguín, M., Rueda-Jasso, R.A. \& Guillaume, J. 2000. Preliminary study on the timing of weaning of spotted sand bass, Paralabrax maculatofasciatus, larvae with a prepared diet: effects on growth and survival. Journal of Applied Aquaculture, 10: 1-15.

Avilés-Quevedo, A., McGregor-Pardo, U., RodríguezRamos, R., Morales-Castro, O., Huerta-Bello, M.A. \& Iizawa, M. 1995. Biología y cultivo de la cabrilla arenera Paralabrax maculatofasciatus (Steindachner, 1868). Centro Regional de Investigaciones Pesqueras, Secretaría de Pesca, La Paz, 35 pp.

Butler, J.L., Moser, H.G., Hageman, G.S. \& Nordgren, L.E. 1982. Developmental stages of three California sea basses (Paralabrax, Pisces, Serranidae). CalCOFI Reports, 22: 252-268.

Civera, R., Ortiz, J.L., Dumas, S., Nolasco, H., Álvarez, A., Anguas, B., Peña, R., Rosales, M., Carrasco, V., García, R. \& Goytortúa, E. 2004. Avances en la nutrición de la cabrilla arenera (Paralabrax maculatofasciatus). In: Cruz-Suárez, L.E., RicqueMarie, D., Tapia-Salazar, M., Gaxiola-Cortés, M.G. \& Simoes, N. (Eds.). Avances en nutrición acuícola VI. Memorias del Sexto Simposium Internacional de Nutrición Acuícola, Universidad Autónoma de Nuevo León, Monterrey, pp. 352-406.

Civera-Cerecedo, R., Álvarez-González, C.A., GarcíaGómez, R.E., Carrasco-Chávez, V., Ortiz-Galindo, J.L., Rosales-Velázquez, M.O., Grayeb-del Álamo, T. \& Moyano-López, F.J. 2008. Effect of microparticulate diets on growth and survival of spotted sand bass larvae, Paralabrax maculatofasciatus, at two early weaning times. Journal of the World Aquaculture Society, 39: 22-36.

Futema-Jiménez, S. 2004. Efecto de la temperatura y salinidad durante el desarrollo embrionario y de la densidad de siembra en la crianza larvaria de Paralabrax maculatofasciatus. Master's Thesis, Centro Interdisciplinario de Ciencias Marinas, Instituto Politécnico Nacional, Ciudad de México, 77 pp.

García-Gómez, R.E. 2003. Efectos en el crecimiento y supervivencia de larva de cabrilla arenera Paralabrax maculatofasciatus en dos tiempos de destete con dietas microparticuladas. Master's Thesis, Universidad Autónoma de Baja California Sur, Baja California Sur, 56 pp.

García-Gómez, R.E. 2006. Uso de dietas microencapsuladas para la alimentación de larvas de la cabrilla arenera Paralabrax maculatofasciatus. Master's Thesis, Centro Interdisciplinario de Ciencias Marinas, Instituto Politécnico Nacional, Ciudad de México, 63 pp.

Grayeb-del Álamo, T. 2001. Efecto de la densidad en el crecimiento de la cabrilla arenera Paralabrax maculatofasciatus (Percoidei: Serranidae) cultivada en jaulas flotantes. Master's Thesis, Centro Interdisciplinario de Ciencias Marinas, Instituto Politécnico Nacional, Ciudad de México, 119 pp.

Hastings, P.A. 1989. Protogynous hermaphroditism in Paralabrax maculatofasciatus (Pisces: Serranidae). Copeia, 1989(1): 184-188.

Lluch-Cota, D.B. 1996. Aspectos reproductivos de la cabrilla arenera, Paralabrax maculatofasciatus (Pises: Serranidae) en Bahía Magdalena-Almejas, Baja California Sur, México. Master's Thesis, Centro Interdisciplinario de Ciencias Marinas, Instituto Politécnico Nacional, Ciudad de México, 186 pp.

Martínez-Brown, J.M. 2007. Efecto del nivel de inclusión de ácidos grasos esenciales y proteína en el alimento de reproductores de cabrilla arenera Paralabrax maculatofasciatus (Percoidei: Serranidae) sobre la calidad de las primeras fases de vida. Master's Thesis, Centro Interdisciplinario de Ciencias Marinas, Instituto Politécnico Nacional, Ciudad de México, 99 pp.

Martínez-Díaz, S., Martínez-Pecero, R., Rosales-Velázquez, M.O., Alvarado-Castillo, R., Pérez-España, H. \& Tucker, J.W. 2001. Voluntary spawning, early development, and completion of the life cycle of spotted sand bass Paralabrax maculatofasciatus in the laboratory. Journal of the World Aquaculture Society, 32: 122-129.

Matus-Nivón, E., Ramírez-Sevilla, R., Martínez-Pecero, R. \& Ortiz-Galindo, J.L. 1990. Potencial acuacultural de ocho especies de peces marinos del Pacífico mexicano, con base en su biología temprana. In: De la Lanza-Espino, G. \& Arredondo-Figueroa, J.L. (Eds.). La acuacultura en México, de los conceptos a la producción. Universidad Autónoma de México, México D.F., 67-74 pp.

Miller, D.J. \& Lea, R.N. 1972. Guide to the coastal marine fishes of California. California Department of Fish and Game. Fish Bulletin, 157: 235 pp.

Ocampo-Cervantes, J.A. 2002. Desarrollo gonádico y actividad reproductiva de la cabrilla arenera Paralabrax maculatofasciatus (Teleostei: Serranidae) en la Bahía de La Paz, Baja California Sur. Master's Thesis, Centro Interdisciplinario de Ciencias Marinas, Instituto Politécnico Nacional, Ciudad de México, 78 pp.

Oda, D.L., Lavenberg, R.J. \& Rounds, J.M. 1993. Reproductive biology of three California species of Paralabrax (Pisces: Serranidae). CalCOFI Reports, 34: 122-132.

Ortiz-Galindo, J.L., Peña, R., Pérez-Gómez, L. \& CastroAguirre, J.L. 2000a. Desarrollo osteológico de la cabrilla arenera Paralabrax maculatofasciatus (Steindachner, 1868) (Percoidei: Serranidae). Memorias VII Con- 
greso Nacional de Ictiología. Universidad Autónoma de México, México D.F., pp. 292-293.

Ortiz-Galindo, J.L., Rosales-Velázquez, M.O., ÁlvarezGonzález, C.A., Grayeb-del Álamo, T. \& Dumas, S. 2000b. Efecto de la temperatura en el desarrollo embrionario de la cabrilla arenera Paralabrax maculatofasciatus (Steindachner, 1868) (Percoidei: Serranidae). Memorias VII Congreso Nacional de Ictiología, Universidad Autónoma de México, México D.F., pp. 82-83.

Peña, R. 2005. Estudios de la función digestiva en larvas de la cabrilla arenera Paralabrax maculatofasciatus: aspectos alimenticios y sus aplicaciones prácticas. Doctorate Thesis, Centro Interdisciplinario de Ciencias Marinas, Instituto Politécnico Nacional, Ciudad de México, 141 pp.

Peña, R. 2015. Criterios de calidad de huevos y sus implicaciones en el cultivo de peces marinos. In: Cruz, L.E., Ricque, D., Tapia, M., Nieto, M., Villarreal, D., Gamboa, J., Rivas, M. \& Miranda, A. (Eds.). Nutrición acuícola: investigación y desarrollo. Universidad Autónoma de Nuevo León, Monterrey, pp. 402-434.

Peña, R. \& Dumas, S. 2005. Effect of delayed first feeding on development and feeding ability of Paralabrax maculatofasciatus larvae. Journal of Fish Biology, 67: 640-651.

Peña, R. \& Dumas, S. 2007. Development of the retina in spotted sand bass Paralabrax maculatofasciatus (Percoidei: Serranidae) larvae under culture conditions. Ciencias Marinas, 33(3): 293-300.

Peña, R. \& Dumas, S. 2009. Development and allometric growth patterns during early larval stages of the spotted sand bass Paralabrax maculatofasciatus (Percoidei: Serranidae). Scientia Marina, 73(S1): 183189.

Peña, R., Dumas, S. \& Rodríguez-Jaramillo, C. 2009. Development and distribution of intestinal enzymatic activity in Paralabrax maculatofasciatus (Steindachner, 1868) larvae fed with live prey. Aquaculture Research, 40: 218-224.

Peña, R., Dumas, S., Villalejo-Fuerte, M. \& OrtizGalindo, J.L. 2003. Ontogenic development of the digestive tract in reared spotted sand bass Paralabrax maculatofasciatus larvae. Aquaculture, 219: 633-644.

Received: 13 June 2018; Accepted: 7 December 2018
Peña, R., Dumas, S., Trasviña, A., García, G. \& PliegoCortés, H. 2005. Effects of tank color and prey density on first feeding of the spotted sand bass Paralabrax maculatofasciatus (Steindachner) larvae. Aquaculture Research, 36: 1239-1242.

Peña, R., Dumas, S., Saldivar-Lucio, R., García, G., Trasviña, A. \& Hernández-Ceballos, D. 2004. The effect of light intensity on first feeding of the spotted sand bass Paralabrax maculatofasciatus (Steindachner) larvae. Aquaculture Research, 35: 345-349.

Pliego-Cortés, H.S. 2005. Evaluación de métodos para determinar la condición nutricional de larvas de cabrilla arenera Paralabrax maculatofasciatus (Percoidei: Serranidae). Master's Thesis, Centro Interdisciplinario de Ciencias Marinas, Instituto Politécnico Nacional, Ciudad de México, 99 pp.

Rodríguez-Trejo, M. 2008. Efecto de diferentes niveles de ácido araquidónico en el alimento de reproductores de cabrilla arenera Paralabrax maculatofasciatus sobre la calidad de embriones y larvas. Master's Thesis, Centro Interdisciplinario de Ciencias Marinas, Instituto Politécnico Nacional, Ciudad de México, 76 pp.

Roldán-Libenson, G., Molina-Camacho, E., CáceresMartínez, C. \& Civera-Cerecedo, R. 1999. Uso del aceite de langostilla como enriquecedor de rotíferos. Efectos sobre el crecimiento y la sobrevivencia de larvas de cabrilla (Paralabrax maculatofasciatus). Hidrobiológica, 9(1): 77-82.

Rosales-Velázquez, M.O. 1997. Efecto de la alimentación sobre los desoves de la cabrilla arenera Paralabrax maculatofasciatus (Teleostei: Serranidae) mantenida en cautiverio. Master's Thesis, Centro Interdisciplinario de Ciencias Marinas, Instituto Politécnico Nacional, Ciudad de México, 70 pp.

Sargent, J., McEvoy, L.A. \& Bell, J.G. 1997. Requirements, presentation and sources of polyunsaturated fatty acids in marine fish larvae feeds. Aquaculture, 155: 117-127.

Secretaría de Pesca y Acuacultura de Baja California (SEPESCA) \& Universidad Autónoma de Baja California Sur (UABCS). 1994. Desarrollo científico y tecnológico del cultivo de la cabrilla. Documento Interno. Universidad Autónoma de Baja California Sur, Baja California Sur, 93 pp.

Shields, R.J. 2001. Larviculture of marine finfish in Europe. Aquaculture, 200: 55-88. 